\title{
Molecular epidemiological study of microtubule-associated protein-like 4-anaplastic lymphoma kinase fusion gene using immunohistochemistry as a cost effective alternative to fluorescence in situ hybridization for Indian patients with adenocarcinoma lung
}

\begin{abstract}
Background: With fluorescence in situ hybridization (FISH) as the main-stay for the detection of anaplastic lymphoma kinase (ALK) rearrangements, the ALK Break Apart FISH Probe Kit has become a Food and Drug Association-approved companion diagnostic for targeted therapy with the ALK inhibitor crizotinib in lung cancers. The objective of this molecular epidemiological study was to estimate the prevalence of microtubule-associated protein-like 4-ALK (EML4-ALK) fusion gene using immunohistochemistry (IHC) as a cost effective alternative to FISH for Indian patients with nonsmall-cell cancer (NSCC)-adenocarcinoma, favor adenocarcinoma lung and NSCC- Not otherwise specified (NOS).

Materials and Methods: Patients with NSCC-adenocarcinoma, favor adenocarcinoma lung, and nonsmall cell lung cancer-NOS histology were considered for this study. Permission was obtained from the Ethics Committee before the start of the study. Clinical characteristics and treatment details were collected from the patient's medical records. IHC analysis was performed using a Ventana automated immunostainer (Benchmark XT). Detection was performed using OptiView DAB Detection and Amplification Kit.

Results: A total of 200 NSCC-adenocarcinoma, favour adenocarcinoma and NSCC-NOS patients were included in the study. There were $122(61 \%)$ men and $78(39 \%)$ women with a median age of 57 years. Of the 200 patients, $43(21.5 \%)$ were nonsmokers and $175(87.5 \%)$ had Stage-IV disease at the time of initial diagnosis. 48 (24\%) cases were positive for epidermal growth factor receptor mutations, whereas EML4-ALK fusion gene was present in $27(13.5 \%)$ patients. 25 of the 27 patients with ALK positivity received crizotinib therapy.

Conclusions: The incidence of EML4-ALK gene fusions (13.5\%) in this Indian population is four-fold high than the previous reported incidences and supports the claim of several recent studies that a relatively new ALK clone, 5A4, and D5F3 from Leica/Novocastra and cell signaling technology/Ventana, respectively can accurately identify ALK rearranged lung adenocarcinoma. The inclusion of IHC for the detection of EML4-ALK gene fusions as a low cost alternative seems justified in low resource setting.
\end{abstract}

Keywords: Anaplastic lymphoma kinase, crizotinib, nonsmall cell lung cancer, Ventana

\section{INTRODUCTION}

Despite significant advancement in the detection and treatment of lung cancer, it still remains a leading cause of cancer-related death worldwide with an overall 5-year survival rate of just $15 \%{ }^{[1]}$ Efforts are underway to develop effective targeted therapy strategies in order to improve the survival of patients with advanced nonsmall-cell cancer (NSCC).

\begin{tabular}{|l|c|}
\hline \multicolumn{2}{|c|}{ Access this article online } \\
\hline \multirow{2}{*}{ Website: } & Quick Response Code \\
\hline www.asjo.in & \\
\hline DOI: & \\
10.4103/ASJO.ASJO_116_16 & \\
\hline
\end{tabular}

\section{Anurag Mehta, Ullas Batra}

Department of Molecular Laboratory and Medical Oncology, Rajiv Gandhi Cancer Institute and Research Center, New Delhi, India

Address for correspondence: Dr. Anurag Mehta, Rajiv Gandhi Cancer Institute and Research Center, Sector-V, Rohini, New Delhi - 110 085, India.

E-mail: amehtargci@gmail.com

This is an open access article distributed under the terms of the Creative Commons Attribution-NonCommercial-ShareAlike 3.0 License, which allows others to remix, tweak, and build upon the work non-commercially, as long as the author is credited and the new creations are licensed under the identical terms.

For reprints contact: reprints@medknow.com

How to cite this article: Mehta A, Batra U. Molecular epidemiological study of microtubule-associated protein-like 4-anaplastic lymphoma kinase fusion gene using immunohistochemistry as a cost effective alternative to fluorescence in situ hybridization for Indian patients with adenocarcinoma lung. Asian J Oncol 2017;3:45-9. 
Studies have shown that around $64 \%$ of NSCC patients harbor at least one activated pathway with mutations in either Kirsten RAS (KRAS) gene or epidermal growth factor receptor (EGFR) gene or the fusion gene of echinoderm microtubule-associated protein-like 4 (EML4) and the intracellular domain of anaplastic lymphoma kinase (ALK), named as EML4-ALK..$^{[2-7]}$

Crizotinib, an oral ATP-competitive tyrosine kinase inhibitors (TKIs) of ALK and c-MET, has shown a good response rate of $57 \%$ and progression free survival (PFS) of $72 \%$ in advanced NSCC, especially in the tumors harboring ALK rearrangements that are negative for EGFR mutation as well as amplification of MET. ${ }^{[8]}$ In an open label Phase 3 trial, crizotinib has demonstrated a median progression free survival and response rate of 7.7 months and $65 \%$ as compared to 3 months and $20 \%$, respectively, in the chemotherapy group $(P<0.001){ }^{[9]}$ A very high 1 and 2 years overall survival of $77 \%$ and $64 \%$, respectively has been reported with crizotinib therapy in patients with advanced NSCC. ${ }^{[10]}$ The presence of EGFR and EML4-ALK mutations in NSCC patients of Indian ethnicity has been reported in the range of $23 \%-44 \%$ and $2.7 \%-3 \%$, respectively. ${ }^{[1-15]}$

Although, the ALK Break Apart FISH Probe Kit (Abbott Molecular, Des Plaines, IL, USA) has become an Food and Drug Association (FDA)-approved companion diagnostic for targeted therapy with crizotinib in lung cancers, the assay can lead to false negatives and false positives along with a very high inter-reader variability. ${ }^{[16]}$ Furthermore, due to the requirement of specialized fluorescence microscopy equipment, fluorescence in situ hybridization (FISH) technique remains an expensive and time-consuming preposition. Immunohistochemistry (IHC) for ALK protein expression in nonsmall cell lung cancer (NSCLC) has been introduced to overcome the limitations of FISH technique. Several recent studies have demonstrated that staining of sections on Ventana immunostainer (Benchmark XT) using an antibody D5F3 and labeling as well as signal amplification kit OptiView by Ventana Roche have a high sensitivity and specificity when compared to FISH. ${ }^{[17-19]}$ Likewise, the 5A4 antibody demonstrate ALK1 protein overexpression has also been found to be satisfactory reports a sensitivity and specificity of $82 \%-100 \%$ compared to the gold standard of FISH. ${ }^{[20-22]}$ However; due to binary nature of interpretation and complete standardization of reagents, controls, and staining protocol Ventana IHC platform for detecting ALK (D5F3) expression has been approved by United States-FDA in the year 2015. We undertook this molecular epidemiological study to estimate the prevalence of EML4-ALK fusion gene using IHC as a cost effective alternative to FISH for Indian patients with adenocarcinoma lung.

\section{MATERIALS AND METHODS}

Patients with NSCC-adenocarcinoma, NSCC favor adenocarcinoma and NSCLC-NOS histology, whose tumors had been tested for EML4-ALK fusion gene using IHC were considered for this study. Permission was obtained from the Ethics Committee before the start of the study. Clinical characteristics and treatment details were collected from the patient's medical records. IHC was assayed on $4-\mu$ m neutral buffered formalin fixed; paraffin-embedded tumor tissues using a primary rabbit monoclonal ALK antibody $(\mathrm{mAb})$ clone D5F3 obtained from Ventana USA. IHC staining was performed using a Ventana Benchmark XT immunostainer (Ventana Medical Systems, Illkirch Graffenstaden, France). The slides were dried for $1 \mathrm{~h}$ at $60^{\circ} \mathrm{C}$, deparaffinized for $4 \mathrm{~min}$ at $75^{\circ} \mathrm{C}$ using EZ Prep followed by incubation at a dilution of 1:50 for $1 \mathrm{~h}$ at $37^{\circ} \mathrm{C}$ with the primary mAb. Detection was performed using a multimer-technology system with the OptiView Universal DAB Detection Kit from the same vendor.

Statistical analysis was performed using Pearson Chi-square or Fisher's exact test, whichever was appropriate for categorical variables. Logistic regression was performed to compare the study groups. A two-sided $P<0.05$ was considered statistically significant. Binary logistic regression with single independent variable was performed and therefore, statistical correction has not been applied to the $P$ values. Statistical analysis was performed using SAS version 9.3 (SAS Institute Inc., Cary NC, USA).

\section{RESULTS}

A total of 200 NSCC adenocarcinoma patients were included in the study. There were $122(61 \%)$ men and $78(39 \%)$ women with a median age of 57 years. Of the 200 patients, 43 (21.5\%) were nonsmokers and 175 (87.5\%) had Stage-IV disease at the time of initial diagnosis. Baseline patient characteristics are presented in Table 1.

The result of molecular testing is shown in Table 2. 48 (24\%) cases were positive for EGFR mutations whereas EML4-ALK fusion gene was present in 27 (13.5\%) patients. 25 out of the 27 patients with ALK positivity received crizotinib therapy.

The association of each of the individual factor with regards to EGFR and EML4-ALK fusion gene mutation is shown in Table 3. While gender and cigarette smoking were significantly associated with EGFR mutation $(P<0.05)$ the EML4-ALK fusion gene mutation showed significant association with gender, cigarette smoking, and performance status $(P<0.05)$. 
Table 1: Summary of patient demographic and tumour characteristics $(n=200)$

\begin{tabular}{|c|c|}
\hline Characteristics & $n(\%)$ \\
\hline Median age (years; range) & $57(22-84)$ \\
\hline \multicolumn{2}{|l|}{ Gender $(\%)$} \\
\hline Male & $122(61)$ \\
\hline Female & $78(39)$ \\
\hline \multicolumn{2}{|l|}{ Smoking (\%) } \\
\hline Smokers & $68(34)$ \\
\hline Never smokers & $43(21.5)$ \\
\hline Unknown & $89(44.5)$ \\
\hline \multicolumn{2}{|l|}{ Grade (\%) } \\
\hline Well differentiated & $4(2)$ \\
\hline $\begin{array}{l}\text { Moderately } \\
\text { differentiated }\end{array}$ & $13(6.5)$ \\
\hline Poorly differentiated & $51(25.5)$ \\
\hline Unknown & $132(66)$ \\
\hline \multicolumn{2}{|l|}{ Stage $(\%)$} \\
\hline I & - \\
\hline ॥ & - \\
\hline III & $3(1.5)$ \\
\hline IV & $175(87.5)$ \\
\hline Unknown & $22(11)$ \\
\hline \multicolumn{2}{|l|}{ Morphology } \\
\hline Papillary & 15 \\
\hline Lepidic & 13 \\
\hline Solid & 10 \\
\hline Acinar & 9 \\
\hline Acinar, solid & 4 \\
\hline Solid, lepidic & 4 \\
\hline Acinar, papillary & 3 \\
\hline Papillary, lepidic & 2 \\
\hline Papillary, solid & 2 \\
\hline Acinar, lepidic & 1 \\
\hline Acinar, papillary, solid & 1 \\
\hline Papillary, solid, lepidic & 1 \\
\hline Unknown & 135 \\
\hline \multicolumn{2}{|l|}{$\mathrm{IHC}$} \\
\hline $\mathrm{p}-63$ & 63 \\
\hline TTF, CK5/CK7 & 47 \\
\hline TTF & 45 \\
\hline CK5/CK7 & 19 \\
\hline $\mathrm{p}-63, \mathrm{TTF}$ & 18 \\
\hline p-63, TTF, CK5/CK7 & 12 \\
\hline p-63, CK5/CK7 & 4 \\
\hline
\end{tabular}

IHC - Immunohistochemistry; TTF - Thyroid transcription factor; CK - Cytokeratin

Table 2: Results of molecular testing $(n=200)$

\begin{tabular}{lc}
\hline Characteristics & $\boldsymbol{n}(\%)$ \\
\hline EGFR mutations & \\
Positive & $48(24)$ \\
Wild type & $152(76)$ \\
EML4-ALK fusion gene & \\
Positive & $27(13.5)$ \\
Wild type & $173(86.5)$ \\
\hline EGFR - Epidermal growth factor receptor; EML4 - Echinoderm microtubule-associated \\
protein-like 4; ALK - Anaplastic lymphoma kinase
\end{tabular}

Table 4 presents the distribution of EGFR and EML4-ALK gene mutations across the study population.

\section{DISCUSSION}

The molecular profiling of the tumor using companion diagnostics followed by subsequent treatment with the relevant targeted therapy has improved the overall survival as well as treatment outcomes in NSCLC. Data from recent studies indicates that the most common mutations in NSCLC are KRAS gene (24\%), EGFR gene (13\%-22\%) and ALK gene rearrangements $(5 \%-6 \%){ }^{[6,7]}$ The use of EGFR TKI for patients with EGFR activating mutations and an oral ATP-competitive TKI of ALK and c-MET, has shown a good response rate in advanced NSCLC. Ever since its approval in the year 2011, crizotinib, has unfolded a new era of personalized treatment in NSCLC tumors harboring ALK rearrangements.

The incidence of EGFR mutation in NSCC has been reported in the range of $13 \%$ for Caucasian population and $47 \%$ for Asian population. ${ }^{[23]}$ Various epidemiological studies of NSCC from India have reported the incidence of EGFR mutation in the range of $23.2 \%-51.8 \%$ with a dominance of female gender. $^{[11-15]}$ The incidence of EGFR mutations (24\%) in our study is lower than the one reported for Asian patients (47\%) but much higher than that for Caucasian patients (13\%). In the present study, a higher EGFR mutation rate was observed in females than males $(12.5 \%$ vs. $11.5 \%, P=0.033)$ and the results were found to be statistically significant. This observation is consistent with the previously published studies that have shown the female gender dominance in the EGFR mutation. ${ }^{[2,13,24,25]}$ The result of our study demonstrates a positive correlation of EGFR mutation in the never smoker group as compared to smokers $(7.5 \%$ vs. $4.5 \%, P=0.029)$.

The incidence of ALK gene rearrangement in NSCLC has been reported in the range of $3 \%$ to $13 \%$ for Caucasian and East Asian population using the FISH technique. ${ }^{[4,26]}$ Two studies from India have reported an incidence of ALK gene rearrangement in NSCLC as $2.7 \%$ and $3 \%$, respectively, using the FISH technique whereas there is no published report on the incidence using the IHC assay. ${ }^{[14,15]}$ Several recent studies have demonstrated a high sensitivity and specificity of Ventana IHC platform for detecting ALK (D5F3) expression using OptiView labeling kit as compared to FISH or other IHC assays. ${ }^{[17-19]}$ Further, patients who are tested FISH-negative and IHC-positive creates diagnostic and therapeutic issues for clinicians in making a right treatment decision. A study by Sun et al. reports a dramatic response to crizotinib therapy in ALK-positive NSCLC patients who are tested FISH negative but IHC-positive. ${ }^{[27]}$ The incidence of ALK gene rearrangement $(13.5 \%)$ in our study is much higher than 
the one reported for Caucasian patients (3\%) as well as the previously reported incidence for Indian population using FISH. In the present study, a higher ALK gene rearrangement rate was observed in females than males $(8.0 \%$ vs. $5.5 \%$, $P=0.020$ ) and the results were found to be statistically significant. The higher positivity as established by IHC can be due to technical difficulties in FISH interpretation and

Table 3: Association of each of the individual factor vis-à-vis epidermal growth factor receptor and echinoderm microtubule-associated protein-like 4-anaplastic lymphoma kinase fusion gene mutations

\begin{tabular}{|c|c|c|c|c|}
\hline \multirow[t]{2}{*}{ Variable } & \multicolumn{2}{|c|}{ EGFR mutations } & \multicolumn{2}{|c|}{ EML4-ALK fusion gene mutation } \\
\hline & $\chi^{2}$ & $\boldsymbol{P}$ & $\chi^{2}$ & $\boldsymbol{P}$ \\
\hline Gender & 4.5443 & $0.0330^{*}$ & 5.3852 & $0.0203^{*}$ \\
\hline Age & 0.6808 & 0.7115 & 3.2135 & 0.2005 \\
\hline Cigarette smoking & 7.0826 & $0.0290^{*}$ & 6.0983 & $0.0474^{*}$ \\
\hline Tobacco chewing & 3.3058 & 0.0690 & 0.1328 & 1.0000 \\
\hline Alcohol intake & 3.3670 & 0.1401 & 0.0262 & 1.0000 \\
\hline Histology & 3.3655 & 0.3386 & 1.7945 & 0.6161 \\
\hline Stage of disease & 3.2712 & 0.3517 & 0.5220 & 0.9140 \\
\hline PS & 7.7636 & 0.1006 & 12.8401 & $0.0121^{*}$ \\
\hline IHC & 9.8735 & 0.6271 & 10.8825 & 0.6207 \\
\hline Morphology & 12.1345 & 0.5955 & 13.2901 & 0.5038 \\
\hline
\end{tabular}

*Significant value. IHC - Immunohistochemistry; PS - Performance status; EGFR - Epidermal growth factor receptor; EML4 - Echinoderm microtubuleassociated protein-like 4; ALK - Anaplastic lymphoma kinase loss of genetic material between 5' portion of ALK gene and 3' portion of EML4 gene during inversion bringing back the signals close together and seemingly fused. The result of our study demonstrates a positive correlation of ALK gene rearrangement in the never smoker group as compared to smokers (3.0\% vs. $2.0 \%, P=0.047)$. Furthermore, there was a positive correlation of ALK gene rearrangement in stage IV patients $(13.0 \%, P=0.012)$.

\section{CONCLUSION}

Our study reports the first Indian data on EML4 ALK fusion gene mutations using IHC as a cost effective alternative to FISH for Indian patients with adenocarcinoma lung. The incidence of EML4-ALK gene fusions (13.5\%) in this Indian population is four-fold high than the previous reported incidences and supports the claim of several recent studies that a relatively new ALK clone, 5A4 and D5F3 from Leica/Novocastra and cell signaling technology/Ventana, respectively can accurately identify ALK rearranged lung adenocarcinoma as compared to FISH. The inclusion of IHC for the detection of EML4-ALK gene fusions as a low cost alternative seems warranted.

Financial support and sponsorship

Nil.

Table 4: Distribution of epidermal growth factor receptor and echinoderm microtubule-associated protein-like 4-anaplastic lymphoma kinase K gene mutations

\begin{tabular}{|c|c|c|c|c|c|c|}
\hline \multirow[t]{2}{*}{ Variable } & \multicolumn{3}{|c|}{ EGFR } & \multicolumn{3}{|c|}{ EML4-ALK fusion gene } \\
\hline & Wild type (\%) & Mutated (\%) & $\boldsymbol{P}$ & Wild type (\%) & Mutated (\%) Y & $\boldsymbol{P}$ \\
\hline \multicolumn{7}{|l|}{ Gender } \\
\hline Female & $53(26.5)$ & $25(12.5)$ & $0.0330^{*}$ & $62(31.0)$ & $16(8.0)$ & $0.0203^{*}$ \\
\hline Male & $99(49.5)$ & $23(11.5)$ & & $111(55.5)$ & $11(5.5)$ & \\
\hline \multicolumn{7}{|l|}{ Age } \\
\hline $20-40$ & $11(5.5)$ & $4(2.0)$ & 0.7115 & $11(5.5)$ & $4(2.0)$ & 0.2005 \\
\hline $40-60$ & $77(38.5)$ & $27(13.5)$ & & $89(44.5)$ & $15(7.5)$ & \\
\hline$>60$ & $64(32.0)$ & $17(8.5)$ & & $73(36.5)$ & $8(4.0)$ & \\
\hline \multicolumn{7}{|l|}{ Smoking history } \\
\hline Never smokers & $30(15.0)$ & $15(7.5)$ & $0.0290^{*}$ & $39(19.5)$ & $6(3.0)$ & $0.0474^{*}$ \\
\hline Smoker & $59(29.5)$ & $9(4.5)$ & & $64(32.0)$ & $4(2.0)$ & \\
\hline Unknown & $63(31.5)$ & $24(12.0)$ & & $70(35.0)$ & $17(8.5)$ & \\
\hline \multicolumn{7}{|l|}{ Stage } \\
\hline I & 0 & 0 & 0.3517 & 0 & 0 & 0.9140 \\
\hline II & 0 & 0 & & 0 & 0 & \\
\hline III & $2(1.0)$ & $1(0.5)$ & & $3(1.5)$ & 0 & \\
\hline IV & $130(65.0)$ & $45(22.5)$ & & $149(74.5)$ & $26(13.0)$ & \\
\hline Unknown & $20(10.0)$ & $2(1.0)$ & & $21(10.5)$ & $1(0.5)$ & \\
\hline \multicolumn{7}{|l|}{ PS } \\
\hline 1 & $26(13.0)$ & $14(7.0)$ & 0.1006 & $34(17.0)$ & $6(3.0)$ & $0.0121^{*}$ \\
\hline 2 & $19(9.5)$ & $3(1.5)$ & & $14(7.0)$ & $8(4.0)$ & \\
\hline 3 & $8(4.0)$ & 0 & & $7(3.5)$ & $1(0.5)$ & \\
\hline 4 & $4(2.0)$ & 0 & & $3(1.5)$ & $1(0.5)$ & \\
\hline Unknown & 95 (47.5) & 31 (15.5) & & $115(57.5)$ & $11(5.5)$ & \\
\hline
\end{tabular}

${ }^{*}$ Significant value. EGFR - Epidermal growth factor receptor; EML4 - Echinoderm microtubule-associated protein-like 4; ALK - Anaplastic lymphoma kinase; PS - Performance status 


\section{Conflicts of interest}

There are no conflicts of interest.

\section{REFERENCES}

1. Jemal A, Siegel R, Ward E, Hao Y, Xu J, Murray T, et al. Cancer statistics, 2008. CA Cancer J Clin 2008;58:71-96.

2. Okamoto I, Mitsudomi T, Nakagawa K, Fukuoka M. The emerging role of epidermal growth factor receptor (EGFR) inhibitors in first-line treatment for patients with advanced non-small cell lung cancer positive for EGFR mutations. Ther Adv Med Oncol 2010;2:301-7.

3. Tsao AS, Papadimitrakopoulou VA. The future of NSCLC: Molecular profiles guiding treatment decisions. Oncology (Williston Park) 2011;25:607, 614.

4. Soda M, Choi YL, Enomoto M, Takada S, Yamashita Y, Ishikawa S, et al. Identification of the transforming EML4-ALK fusion gene in non-small-cell lung cancer. Nature 2007;448:561-6.

5. Zhang X, Zhang S, Yang X, Yang J, Zhou Q, Yin L, et al. Fusion of EML4 and ALK is associated with development of lung adenocarcinomas lacking EGFR and KRAS mutations and is correlated with ALK expression. Mol Cancer 2010;9:188.

6. Sequist LV, Heist RS, Shaw AT, Fidias P, Rosovsky R, Temel JS, et al. Implementing multiplexed genotyping of non-small-cell lung cancers into routine clinical practice. Ann Oncol 2011;22:2616-24.

7. Kris MG, Johnson BE, Kwiatkowski DJ. Identification of driver mutations in tumor specimens from 1,000 patients with lung adenocarcinoma: The NCI's Lung Cancer Mutation Consortium (LCMC). J Clin Oncol 2011;29 (Suppl):Abstr CRA7506.

8. Kwak EL, Bang YJ, Camidge DR, Shaw AT, Solomon B, Maki RG, et al. Anaplastic lymphoma kinase inhibition in non-small-cell lung cancer. N Engl J Med 2010;363:1693-703.

9. Shaw AT, Kim DW, Nakagawa K, Seto T, Crinó L, Ahn MJ, et al. Crizotinib versus chemotherapy in advanced ALK-positive lung cancer. N Engl J Med 2013;368:2385-94.

10. Shaw AT, Yeap BY, Solomon BJ, Riely GJ, Iafrate AJ, Shapiro G, et al. Impact of crizotinib on survival in patients with advanced, ALK positive NSCLC compared with historical controls. J Clin Oncol 2011;29 (Suppl): Abstr 7507.

11. Sahoo R, Harini VV, Babu VC, Patil Okaly GV, Rao S, Nargund A, et al. Screening for EGFR mutations in lung cancer, a report from India. Lung Cancer 2011;73:316-9.

12. Chougule A, Prabhash K, Noronha V, Joshi A, Thavamani A, Chandrani P, et al. Frequency of EGFR mutations in 907 lung adenocarcioma patients of Indian ethnicity. PLoS One 2013;8:e76164.

13. Doval DC, Azam S, Batra U, Choudhury KD, Talwar V, Gupta SK, et al. Epidermal growth factor receptor mutation in lung adenocarcinoma in India: A single center study. J Carcinog 2013;12:12.

14. Desai SS, Shah AS, Prabhash K, Jambhekar NA. A year of anaplastic large cell kinase testing for lung carcinoma: Pathological and technical perspectives. Indian J Cancer 2013;50:80-6.
15. Doval D, Prabhash K, Patil S, Chaturvedi H, Goswami C, Vaid A, et al. Clinical and epidemiological study of EGFR mutations and EML4-ALK fusion genes among Indian patients with adenocarcinoma of the lung. Onco Targets Ther 2015;8:117-23.

16. Wallander ML, Geiersbach KB, Tripp SR, Layfield LJ. Comparison of reverse transcription-polymerase chain reaction, immunohistochemistry, and fluorescence in situ hybridization methodologies for detection of echinoderm microtubule-associated proteinlike 4-anaplastic lymphoma kinase fusion-positive non-small cell lung carcinoma: Implications for optimal clinical testing. Arch Pathol Lab Med 2012;136:796-803.

17. Marchetti A, Di Lorito A, Pace MV, Iezzi M, Felicioni L, D’Antuono T, et al. ALK Protein analysis by IHC staining after recent regulatory changes: A comparison of two widely used approaches, revision of the literature, and a new testing algorithm. J Thorac Oncol 2016;11:487-95.

18. von Laffert M, Warth A, Penzel R, Schirmacher P, Kerr KM, Elmberger G, et al. Multicenter immunohistochemical ALK-testing of non-small-cell lung cancer shows high concordance after harmonization of techniques and interpretation criteria. J Thorac Oncol 2014;9:1685-92.

19. Pekar-Zlotin M, Hirsch FR, Soussan-Gutman L, Ilouze M, Dvir A, Boyle T, et al. Fluorescence in situ hybridization, immunohistochemistry, and next-generation sequencing for detection of EML4-ALK rearrangement in lung cancer. Oncologist 2015;20:316-22.

20. McLeer-Florin A, Moro-Sibilot D, Melis A, Salameire D, Lefebvre C, Ceccaldi F, et al. Dual IHC and FISH testing for ALK gene rearrangement in lung adenocarcinomas in a routine practice: A French study. J Thorac Oncol 2012;7:348-54.

21. Paik JH, Choe G, Kim H, Choe JY, Lee HJ, Lee CT, et al. Screening of anaplastic lymphoma kinase rearrangement by immunohistochemistry in non-small cell lung cancer: Correlation with fluorescence in situ hybridization. J Thorac Oncol 2011;6:466-72.

22. Glassco J, Kyshtoobayeva A, Bloom KJ. Assessment of the ALK antibody, 5A4 in detecting ALK rearrangments in non-small cell lung cancer specimens. In: Laboratory Investigation. Vol. 92. New York, USA: Nature Publishing Group; 2012. p. 476A-7A.

23. Sekine I, Yamamoto N, Nishio K, Saijo N. Emerging ethnic differences in lung cancer therapy. Br J Cancer 2008;99:1757-62.

24. Smits AJ, Kummer JA, Hinrichs JW, Herder GJ, Scheidel-Jacobse KC, Jiwa NM, et al. EGFR and KRAS mutations in lung carcinomas in the Dutch population: Increased EGFR mutation frequency in malignant pleural effusion of lung adenocarcinoma. Cell Oncol (Dordr) 2012;35:189-96.

25. Tanaka T, Matsuoka M, Sutani A, Gemma A, Maemondo M, Inoue A, et al. Frequency of and variables associated with the EGFR mutation and its subtypes. Int J Cancer 2010;126:651-5.

26. Wong DW, Leung EL, So KK, Tam IY, Sihoe AD, Cheng LC, et al. The EML4-ALK fusion gene is involved in various histologic types of lung cancers from nonsmokers with wild-type EGFR and KRAS. Cancer 2009;115:1723-33.

27. Sun JM, Choi YL, Won JK, Hirsch FR, Ahn JS, Ahn MJ, et al. A dramatic response to crizotinib in a non-small-cell lung cancer patient with IHC-positive and FISH-negative ALK. J Thorac Oncol 2012;7:e36-8. 